\title{
Assessing the carrying capacity of Perinereis aibuhitensis in a Chinese estuarine wetland using a GIS-based habitat suitability index model
}

\author{
Chengyue Liu ${ }^{1}$, Qixiang Wang ${ }^{2}$, Wenxi Zhao ${ }^{3}$, Hongjun Liu ${ }^{3}$, Xuexi Tang ${ }^{4}$, \\ Zhipeng Zhang ${ }^{4}$, Jian Zhou ${ }^{2, *}$ \\ ${ }^{1}$ Key Laboratory of Mariculture, Ministry of Education, Ocean University of China, Qingdao 266003, PR China \\ ${ }^{2}$ Shandong Marine Forecast and Hazard Mitigation Service, Qingdao 266104, PR China \\ ${ }^{3}$ Marine Biology Institute of Shandong Province, Qingdao 266104, PR China \\ ${ }^{4}$ College of Marine Life, Ocean University of China, Qingdao 266100, PR China
}

\begin{abstract}
Increasing attention is being paid to estuarine benthic community conservation and restoration globally. In this study, a GIS-based habitat suitability index (HSI) model was utilized to estimate Perinereis aibuhitensis (Grube, 1878) carrying capacity in estuarine wetlands of the Zhimai River, eastern China. Eight parameters were investigated, including sand content, salinity, $\mathrm{pH}$, and petroleum hydrocarbon. Each parameter was investigated by a non-linear suitability function for transition from transformed parameter values into a normalized quality index. The weight of each parameter factor was determined by an analytic hierarchy process. A functional relationship was established between habitat suitability and population abundance to assess the carrying capacity. Twelve observation stations, divided into central, eastern, and western regions, were selected to collect data on biogeochemical and environmental parameters. These data were interpolated by GIS. The HSI model was then applied to obtain thematic maps of suitable habitat areas for $P$. aibuhitensis and corresponding carrying capacities. Results showed that central and western regions (approximately $1.013 \mathrm{~km}^{2}$, accounting for $66.38 \%$ of the total area) had a relatively high carrying capacity $\left(130-150\right.$ ind. $\left.\mathrm{m}^{-2}\right)$, whereas the carrying capacity of the eastern region was below average. The abundance of $P$. aibuhitensis did not reach the carrying capacity of the environment under present conditions, especially in the eastern region. Results of the present study indicate that the execution of $P$. aibuhitensis restoration is feasible in this region; the areas around Stn 7 and in the eastern region are recommended for restoration.
\end{abstract}

KEY WORDS: Carrying capacity · Habitat suitability index model · HSI · Geographical information system · GIS · Perinereis aibuhitensis · Zhimai River

\section{INTRODUCTION}

The polychaete Perinereis aibuhitensis (Grube, 1878) is widely distributed along Asian coastlines and estuaries, and is regarded as a good bio-indicator of metal and organic pollution (Sun et al. 2009, Yuan et al. 2010). Moreover, P. aibuhitensis, as a high-quality bait in aquaculture (fish, shrimps, and crabs), is a rich source of protein and provides some essential fatty

${ }^{*}$ Corresponding author: zhoujian.park@163.com acids. In China, it is often used as an important food source in fish farming (Zhang \& Hu 2008). As an ecological keystone species, $P$. aibuhitensis, like other Polychaeta, can scavenge detritus and organic matter on the sediment surface, and plays a key role in nutrient recycling in water-sediment coupling (Davey \& Watson 1995, Durou et al. 2005, 2007).

On the west coast of Laizhou Bay in northern China, estuarine wetlands of the Zhimai River com-

(C) The authors 2017. Open Access under Creative Commons by Attribution Licence. Use, distribution and reproduction are unrestricted. Authors and original publication must be credited. 
prise important tidal flats (Shao et al. 2015) in which $P$. aibuhitensis is the dominant species. Due to rapid economic development, overfishing, and anthropogenic marine pollution, $P$. aibuhitensis habitats have been seriously degraded. The natural population of $P$. aibuhitensis has been declining on an annual basis and therefore requires urgent restoration and conservation (Zhang \& Hu 2008).

Carrying capacity predictions are a necessary step in species conservation and restoration (McKeon et al. 2009, Guyondet et al. 2015). McKeon et al. (2009) and Steenweg et al. (2016) indicated that carrying capacity is significantly related to species habitat. If all suitable habitats in a particular location reach their carrying capacity, augmenting the population through species reintroduction will not facilitate population growth without habitat enhancement or restoration. Similarly, if a non-habitat factor is the main limitation of the population, habitat improvement or restoration will have no effect on population growth (Downs et al. 2008, McKeon et al. 2009, Steenweg et al. 2016). Estimates of the habitat carrying capacity can provide an effective and feasible measure of fish production for the sustainable development and management of aquaculture (Downs et al. 2008).

The habitat suitability index (HSI) model (USFWS 1981) is extensively used to predict habitat quality and species distributions, and to assess reserve and management priorities (Downs et al. 2008, Zajac et al. 2015). Vincenzi et al. (2006) estimated the annual potential yield of Tapes philippinarum using HSI values to provide important management decisions for sustainable development in a Mediterranean coastal lagoon (Sacca di Goro, Italy). Another HSI model was developed by Steenweg et al. (2016) to evaluate habitat quality and to assess whether there was sufficient habitat for a breeding population in the proposed reintroduction of plains bison Bison bison bison into Banff National Park (Canadian Rocky Mountains).

When evaluating habitat suitability, the need to use data from different sources and scales usually complicates the task and leads to increased data volumes (Store \& Jokimäki 2003, Brach \& Kaczmarowski 2014). GIS has been utilized in ecological modeling as a means of producing the required modeling data on different spatial and temporal scales (Carter et al. 2006, Mathys et al. 2006). GIS acts as a platform on which models are run and data are stored (Brown et al. 1994, Ripple et al. 1997), and can be used as a tool for extrapolating the results from a point basis to a spatial basis (Littleboy et al. 1996, Osborne et al. 2001).

The 2 aims of the present study were to (1) apply a GIS-based HSI model to evaluate habitat suitability and estimate $P$. aibuhitensis carrying capacity in the estuarine wetlands of the Zhimai River, China, and (2) compare estimated carrying capacity with that under present conditions to provide feasible suggestions for $P$. aibuhitensis conservation and restoration.

\section{MATERIALS AND METHODS}

\section{Study area}

The study area $\left(1.5 \mathrm{~km}^{2}\right)$ was located in the southern region of the Zhimai River estuary tidal flat, adjacent to the Dongying Guangrao Nereis National Special Marine Reserve (Dongying City, Shandong Province, China), and to the east of Lai Zhou Bay (Bohai Sea, China). The study area is surrounded by salt fields and undeveloped land. Salinity ranges from 9 to $20 \%$, and $\mathrm{pH}$ fluctuations are small (8.158.53). The sediment type here comprises mainly muddy silt, and the main plant species include the common reed Phragmites australis and saline seepweed Suaeda salsa. The oil industry has always been a main industry in Dongying City. Therefore, petroleum exploration and production will likely impact the Zhimai River, with petroleum hydrocarbon and heavy metal (lead, copper, etc.) acting as potential environmental stressors in this area.

\section{Sample collection and analysis}

Eastern, central, and western regions of the study area were established to include a total of 4 sections and 12 observation stations (Fig. 1, eastern: Stns 1-3, central: Stns 4-9, western: Stns 10-12). Four field sampling campaigns were conducted in November 2010, March 2011, May 2011, and August 2011. Water quality and intertidal sediment characteristics were determined at these stations. Due to limitations in manpower, time, and funding, Perinereis aibuhitensis abundance was only determined at 6 stations (Stns 1-3 and 7-9). For each sampling campaign and station, 3 replicate soil samples were collected from 0 to $40 \mathrm{~cm}$ depth by a Van Veen grab $\left(0.02 \mathrm{~m}^{2}\right)$, and 4 replicates for $P$. aibuhitensis abundance were determined in a $0.016 \mathrm{~m}^{2}(40 \times 40 \mathrm{~cm})$ stainless steel sampling box (depth of $40 \mathrm{~cm}$ ). All $P$. aibuhitensis samples were washed through a $1 \mathrm{~mm}$ mesh sieve, then counted and preserved in a $10 \%$ buffered formalin solution (Zhao et al. 1993). Species identification was assisted by marine taxonomy experts at the Marine Biology Institute of Shandong Province. 


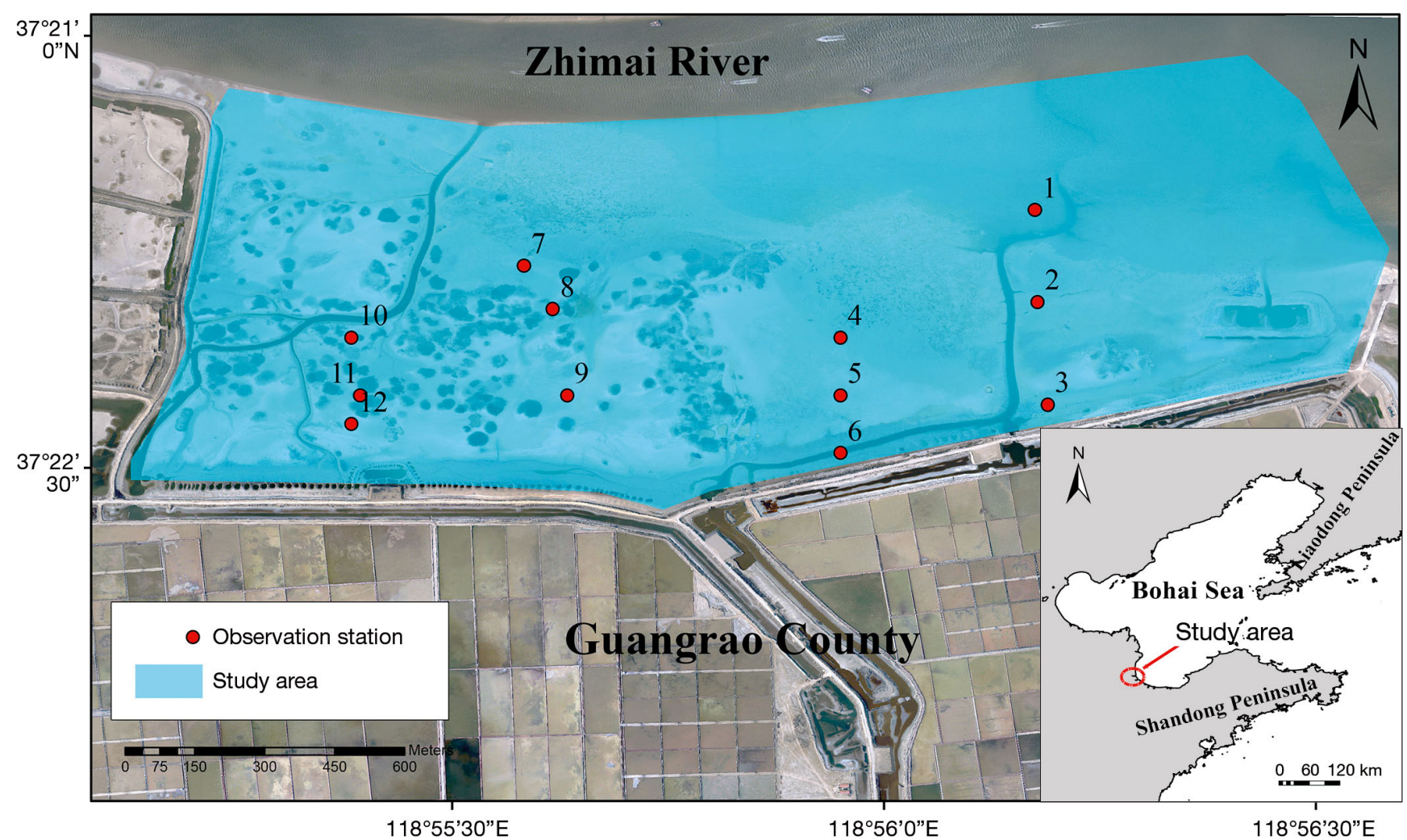

Fig. 1. Study area and monitoring stations in the estuarine wetlands of the Zhimai River, Laizhou Bay, northern China

All soil samples were air-dried by a vacuum refrigeration dryer (Marin Christ, Epsilon 2-6D), then powdered and sieved through a $0.149 \mathrm{~mm}$ nylon sieve to remove coarse debris. The concentrations of lead, copper, and cadmium in the soil were measured by inductively coupled plasma atomic emission spectrometry (JOBINYVON Company, ULTIMA 2) after digestion by an $\mathrm{HCLO}_{4}-\mathrm{HNO}_{3}$ - $\mathrm{HF}$ mixed solution described in Bai et al. (2011). Petroleum hydrocarbon was extracted from the soil with $n$-hexane and determined using an ultraviolet spectrophotometer (Shimadzu, UV-3600) (Yang et al. 2015). Sulfide was determined through methylene blue spectrophotometry according to the method of Alves et al. (2007). Quality assurance and control were assessed using duplicates, method blanks, and standard reference materials (GBW07401 and GBW080913) from the National Research Center for Standards in China with each batch of samples. The recovery rates for samples spiked with standards ranging from 95 to $105 \%$. The measurement of $\mathrm{pH}$, salinity, and sediment grain size was based on the method of Bai et al. (2011). Soil pH was determined by a Hach pH meter (Hach Company, LPV2500). A VWR scientific conductivity meter (VWR Scientific Products, 1410) was used to measure the electrical conductivity. The sed- iment grain size distribution was determined using a laser particle size analyzer (Malvern Instruments, MS2000).

\section{Model methods}

First, the parameter factors were screened. The parameter factor suitability functions were built and each parameter factor was determined by an analytic hierarchy process (AHP) and expert suggestions. Second, the HSI model was calculated using ArcGIS 10.0 software (ESRI) to obtain $P$. aibuhitensis habitat suitability values. Third, the function was constructed between the HSI value and carrying capacity. Finally, $P$. aibuhitensis carrying capacity was estimated using the HSI model (Fig. 2).

\section{Model variables}

Information on species-habitat relationships and life history are the basic requirements of the HSI model design (Vincenzi et al. 2006). Based on our data and previous studies (Miron \& Kristensen 1993, Shi 1993, Ahn et al. 1995, Reish \& Gerlinger 1997, Gu 


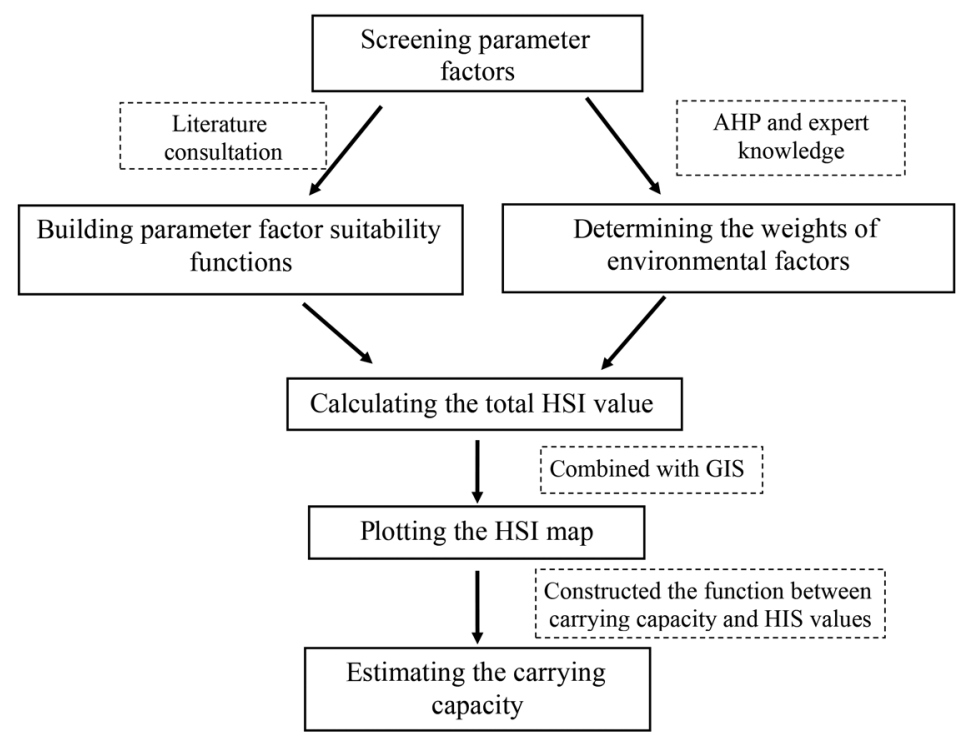

Fig. 2. Research method flow chart. AHP: analytic hierarchy process; GIS: global information system; HSI: habitat suitability index sis farming (Zhang \& Hu 2008). Optimal substrate is characterized by a high proportion of silt and clay (slit and clay $\leq 125 \mu \mathrm{m}$ ), and a specific percentage of sand $(25-50 \% ; 125 \mu \mathrm{m}<$ sand $\leq 250 \mu \mathrm{m})$ (Fauchald 1986, Ahn et al. 1995, Cai \& Li 1995).

\section{Salinity}

Salinity affects the survival and growth of $P$. aibuhitensis during all of its life stages. $P$. aibuhitensis can grow and develop normally in a salinity range of $8-45 \%$; however, its optimal salinity range is 24-28\% (Ushakova \& Sarantchova 2004, Lv et al. 2009, Cai \& Yan 2014).

$\mathrm{pH}$
\& Jin 2002, Lv et al. 2009, Yuan et al. 2010, Cai \& Yan 2014, Tian et al. 2014), environmental quality factors and environmental pollution factors were selected as input variables for the HSI model. The environmental quality factors included sand content $(\%)$, salinity $(\% \circ)$, and $\mathrm{pH}$. The environmental pollu-

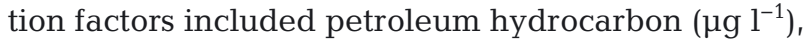
lead $\left(\mathrm{mg} \mathrm{l}^{-1}\right)$, copper $\left(\mu \mathrm{g} \mathrm{l}^{-1}\right)$, cadmium $\left(\mu \mathrm{g} \mathrm{l}^{-1}\right)$, and sulfide $\left(\mathrm{mg} \mathrm{l}^{-1}\right)$.

\section{Parameter factor suitability functions}

Parameter factor suitability functions (PFSFs) were defined to evaluate the suitability of particular locations relating to environmental parameters (Ortigosa et al. 2000, Vincenzi et al. 2006). For each variable, the suitability index (SI) was determined on an arbitrary scale between 0 and 1, where 0 was identified as a non-suitable habitat, and 1 was assigned to the most suitable condition. PFSFs are presented in Fig. 3. The PFSFs used in this study were compared with previous literature, as briefly illustrated hereafter.

\section{Environmental quality factors}

\section{Sand content}

Estuary substrate exerts a large influence on $P$. aibuhitensis distribution. Rocky (rock and gravel: $>250 \mu \mathrm{m}$ ) sediments are unsuitable for $P$. aibuhiten-
$\mathrm{pH}$ has a significant influence on the fertility and embryonic development of $P$. aibuhitensis. Optimal fertilization and hatching rates occur in $\mathrm{pH}$ 7.0-7.5, while $P$. aibuhitensis cannot fertilize $<\mathrm{pH} 6.0$ (Shi 1993, Zhou et al. 2007, Zhang \& Hu 2008).

\section{Environmental pollution factors}

\section{Petroleum hydrocarbon}

Petroleum hydrocarbon is highly toxic to Polychaeta (Sun et al. 2009). Previous studies showed that exposure to $3 \mu \mathrm{g} \mathrm{l}^{-1}$ of petroleum hydrocarbon did not result in mortality (Sun et al. 2006, Wang et al. 2007, 2008a); however, Wang et al. (2008a) reported that after an $8 \mathrm{~d}$ exposure to $30 \mu \mathrm{g} \mathrm{l^{-1 }}$, the mortality rate was $20 \%$.

\section{Copper}

The accumulation of copper increases in body tissues under elevated concentrations (Won et al. 2013). Results of previous studies demonstrated that the activity of antioxidase and acetylcholinesterase changes when $P$. aibuhitensis is exposed to copper (Sun et al. 2006, Wang et al. 2007). After a 3 d exposure to copper, the value of lethal concentration 50 $\left(\mathrm{LC}_{50}\right)$ was shown to be $500 \mu \mathrm{g}^{-1}$; the most suitable concentration recorded was $<45 \mu \mathrm{g}^{-1}$ (Sun et al. 2006, 2009, Wang et al. 2007). 


\section{Cadmium}

Cadmium is one of the most highly toxic heavy metals; it is widely distributed and can be accumulated in vivo. P. aibuhitensis has been shown to be sensitive to this heavy metal pollutant, especially $\mathrm{Cd}^{2+}$ ( $\mathrm{Ng}$ et al. 2008, Wang et al. 2008a, Yuan et al. 2010). Ng et al. (2008) reported elevated metallothionein turnover (synthesis and breakdown) rates in $P$. aibuhitensis after $\mathrm{Cd}^{2+}$ pre-exposure. For P. aibuhitensis, the $96 \mathrm{~h} \mathrm{LC}_{50}$ of cadmium has been shown to be $1000 \mu \mathrm{g} \mathrm{l}^{-1}$, with the most suitable concentration being $<80 \mu \mathrm{g} \mathrm{l}^{-1}$ (Wang et al. 2008a).

\section{Lead}

Lead-induced oxidative stress contributes to the pathogenesis of lead poisoning, resulting in the disruption of the delicate prooxidant/antioxidant balance in polychaetes (Chiba et al. 1996, Tian et al. 2014). The $96 \mathrm{~h} \mathrm{LC} \mathrm{LC}_{50}$ value of lead for adult $P$. aibuhitensis is $680 \mathrm{mg} \mathrm{l}^{-1}$. When the concentration of lead is $<50 \mathrm{mg} \mathrm{l}^{-1}$ (safe concentration in the chronic lead toxicity test), $P$. aibuhitensis can grow and develop normally (Tian et al. 2014).

\section{Sulfide}

Sulfide has a small effect on adult Nereis spp. (Fauchald 1986, Miron \& Kristensen 1993). However, acute toxicity test results have demonstrated significant effects of sulfide on the survival rate of 3-setiger nectochaeta (Miron \& Kristensen 1993). The safe sulfide concentration for 3-setiger nectochaeta (juvenile $P$. aibuhitensis) is $<600 \mathrm{mg} \mathrm{l}^{-1}$, with values $<300 \mathrm{mg} \mathrm{l}^{-1}$ being the most suitable.

\section{Weights of parameter factors}

Although the effects of environmental factors vary among different organisms, identification of the relative factor weights is important in the development of an HSI model. The AHP is a method used for calculating the weights of parameter factors by qualitative and quantitative comparison of their relative importance (Saaty 1977, Saaty \& Vargas 1991). In many sustainable habitat management models, AHP is widely used to create a methodology framework and reduce uncertainty (Store \& Kangas 2001, Luan et al. 2011, Chen et al. 2013). For example, using
AHP, Shen et al. (2008) identified the relative importance of habitat factors to determine the range of giant panda activity in the Minshan Mountains, China.

In the present study, considering the issues being addressed and the final objectives, hierarchy was used to change a complex unstructured problem into a simplified structured model. Each parameter factor was assigned a numerical value by comparing the relative importance (Saaty \& Vargas 1991). Questionnaires were sent to appropriate experts to evaluate the relative importance of the 8 parameter factors. The results of the questionnaires were collected and averaged, and the AHP was then run; 'YAAHP' (Yet another AHP) software was applied to determine the weight of the variables using a matrix (Table 1).

The consistency ratio (CR) ratings of the matrices should be below 0.1 ; if they exceed this value, revisions to the matrix evaluations are required (Saaty 1977). In the present study, the CR of the environmental quality factors and environmental pollution factors was 0.0036 and 0.0115 , respectively. Therefore, the results shown in Table 2 were considered reasonable and did not require revision. Weights of parameter factors are presented in Table 2, including sand content, salinity, $\mathrm{pH}$, and petroleum hydrocarbon.

\section{HSI calculation}

With regard to the GIS spatial analysis module, the inverse distance weighted interpolation method was used for data interpolation. The HSI value of the study area was calculated by the score of each parameter factor. The HSI value represents the habitat's capacity to carry a particular species. An HSI model can quantitatively measure habitat quality and suitability using knowledge of the species' normal growth and reproduction habitat requirements (Hickey 2008, Knudson et al. 2015). In the present study, the HSI value is the sum of each parameter factor SI multiplied by the corresponding weight (Wang et al. 2008b, Acevedo \& Cassinello 2009, Gumusay et al. 2016). The HSI model algorithm was as follows:

$$
\mathrm{HSI}=\sum_{i=1}^{8} \mathrm{SI}_{i} \cdot W_{i}
$$

where $\mathrm{SI}_{i}$ is the suitability index value of a specific factor according to Fig. $3 ; W_{i}$ is the weight corresponding to a specific factor; and $i(=1-8)$ is the index corresponding to the 8 input factors of the model. 
Table 1. Index weight values of (A) habitat suitability index model variables, (B) environmental quality factors, and (C) environmental pollution factors. Fractions indicate relative weighting of variables - numerator: row variable; denominator: column variable

\begin{tabular}{|c|c|c|c|c|c|}
\hline $\begin{array}{l}\text { (A) } \\
\text { Model variables }\end{array}$ & \multicolumn{2}{|c|}{ Environmental quality factors } & \multicolumn{3}{|c|}{ Environmental pollution factors } \\
\hline Environmental quality factors & $1 / 1$ & & & $3 / 1$ & \\
\hline Environmental pollution factors & $1 / 3$ & & & $1 / 1$ & \\
\hline \multirow{2}{*}{$\begin{array}{l}\text { (B) } \\
\text { Environmental quality factors }\end{array}$} & \multirow{2}{*}{\multicolumn{2}{|c|}{ Sediment composition }} & & & \\
\hline & & & \multicolumn{2}{|c|}{ Salinity } & $\mathrm{pH}$ \\
\hline Sediment composition & $1 / 1$ & & & & $5 / 1$ \\
\hline Salinity $\quad 1$ & $1 / 3$ & & & & $2 / 1$ \\
\hline $\mathrm{pH}$ & $1 / 5$ & & & & $1 / 1$ \\
\hline \multicolumn{6}{|l|}{ (C) } \\
\hline Environmental pollution factors & Petroleum hydrocarbon & Lead & Copper & Cadmium & Sulfide \\
\hline Petroleum hydrocarbon & $1 / 1$ & $3 / 1$ & $4 / 1$ & $4 / 1$ & $5 / 1$ \\
\hline Lead & $1 / 3$ & $1 / 1$ & $2 / 1$ & $2 / 1$ & $3 / 1$ \\
\hline Copper & $1 / 4$ & $1 / 2$ & $1 / 1$ & $1 / 1$ & $2 / 1$ \\
\hline Cadmium & $1 / 4$ & $1 / 2$ & $1 / 1$ & $1 / 1$ & $2 / 1$ \\
\hline Sulfide & $1 / 5$ & $1 / 3$ & $1 / 2$ & $1 / 2$ & $1 / 1$ \\
\hline
\end{tabular}

Table 2. Defined weights of parameter factors calculated by the analytical hierarchy process method

\begin{tabular}{|lccccccc|}
\hline Sediment composition & Salinity & $\mathrm{pH}$ & Petroleum hydrocarbon & Lead & Cadmium & Copper & Sulfide \\
\hline 0.4860 & 0.1724 & 0.0196 & 0.1190 & 0.0526 & 0.0303 & 0.0303 & 0.0178 \\
\hline
\end{tabular}

\section{Map plotting}

To make the assessment results more intuitive, the HSI values were reclassified to create habitat suitability maps with gradient colors. Following this, map projection transformation was performed and the value of each class of HSI area was calculated by raster statistics. Both reclassification and projection transformation were implemented using ArcGIS 10.0 software.

\section{Estimating carrying capacity}

The HSI model identifies suitable regions for $P$. aibuhitensis using habitat information, but it does not quantify the availability of the study area. With expert evaluation (H. Liu pers. obs.) and field observations, the function between $P$. aibuhitensis carrying capacity and HSI values was constructed through modification of the method by Vincenzi et al. (2011). The maximum carrying capacity of the most suitable habitats (those with $\mathrm{HSI} \geq 0.9$ ) was 148 ind. $\mathrm{m}^{-2}$ (the average of the pre-survey). When the HSI was $<0.2$, theoretically, normal growth could not occur; therefore, it was assumed that $P$. aibuhitensis abundance would be negligible. Consequently, the carrying capacity can be determined by linearly scaling the HSI between 0.2 and 0.9 , as follows:

$$
\mathrm{CC}= \begin{cases}0 & \text { if } 0 \leq \mathrm{HSI} \leq 0.2 \\ 211 \mathrm{HSI}-42.2 & \text { if } 0.2<\mathrm{HSI}<0.9 \\ 148 & \text { if } 0.9 \leq \mathrm{HSI} \leq 1\end{cases}
$$

where CC is the $P$. aibuhitensis carrying capacity.

\section{RESULTS}

Overall, this region contained a suitable level of habitat for Perinereis aibuhitensis; the HSI value ranged from 0.64 to 0.92 (Fig. 4). Approximately $70 \%$ $\left(1.062 \mathrm{~km}^{2}\right)$ of the study area exhibited HSI values $>0.80$, with the most suitable habitats found around Stn 5 (HSI > 0.90; Table 3). In contrast, the HSI values of the eastern region (Stns 1-3) were relatively low (0.64-0.80), especially at Stn 3 (only 0.64). Moreover, a small area near Stn 7 also exhibited an HSI value $<0.80$ (Fig. 4). 

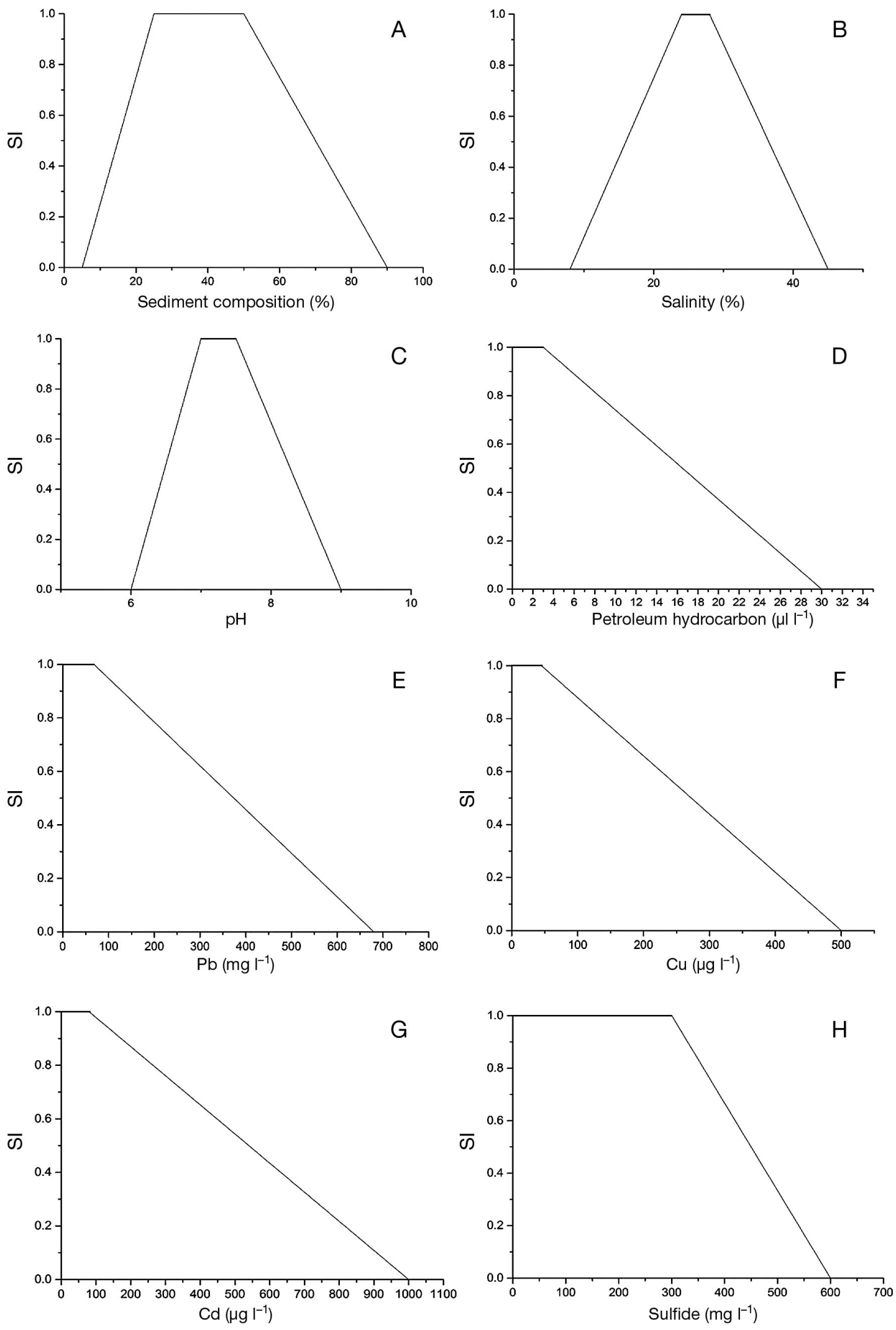

Fig. 3. Parameter factor suitability functions for: (A) sand content; (B) salinity; (C) $\mathrm{pH}_{i}(\mathrm{D})$ petroleum hydrocarbon; (E) lead; (F) copper; (G) cadmium; and (H) sulfide. SI, suitability index 


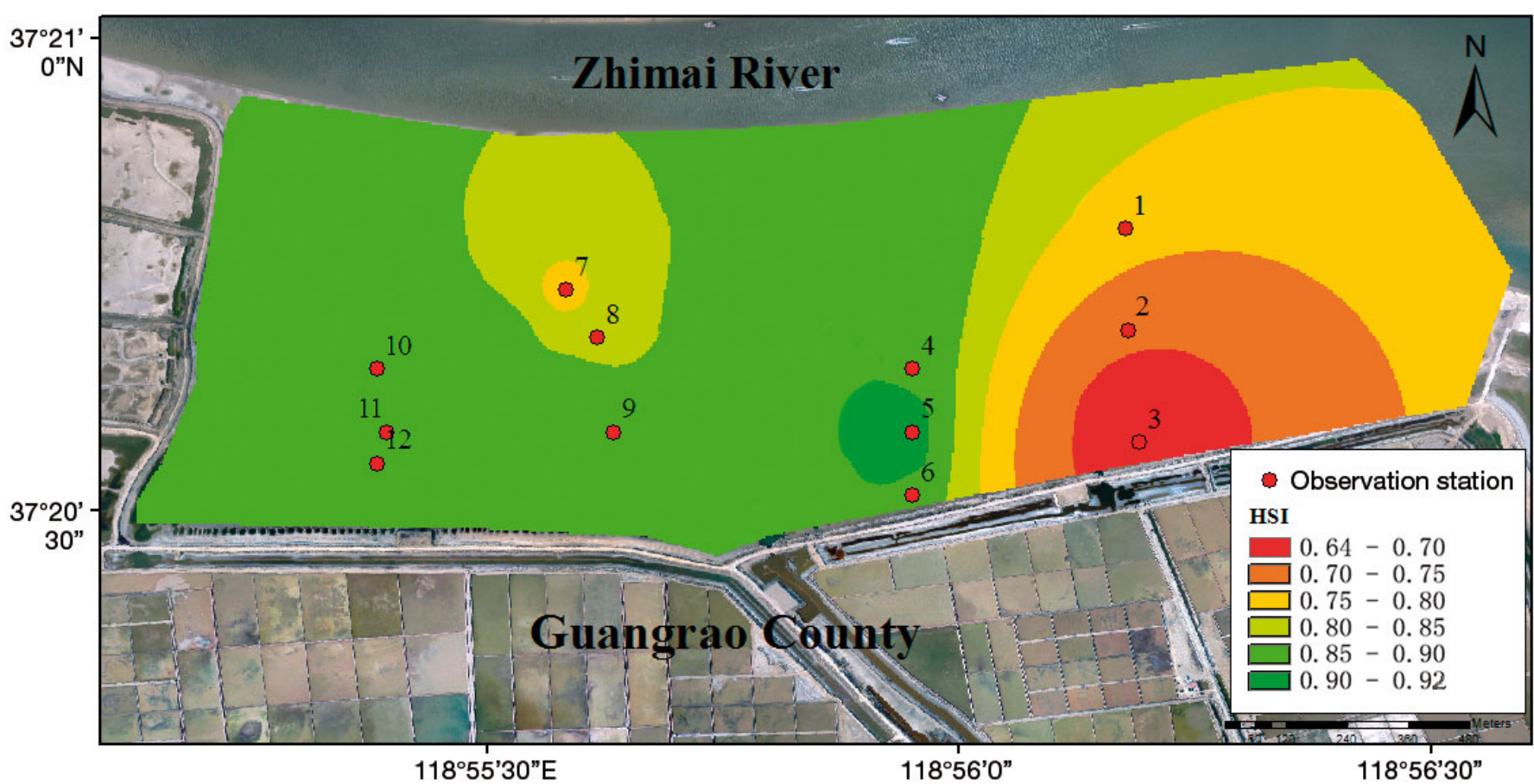

Fig. 4. Habitat suitability map for Perinereis aibuhitensis in the estuarine wetlands of the Zhimai River. HSI: habitat suitability index

The area of 6 different carrying capacity classes was calculated by GIS, and then the carrying capacity of each class was estimated using the average value (Table 4). The total abundance of $P$. aibuhitensis was approximately $2.03 \times 10^{8}$ individuals and the average carrying capacity was 130 ind. $\mathrm{m}^{-2}$. These calculations are comparable with those of other studies in some estuarine wetlands of northern China (Fauchald 1986, Zhao et al. 1993).
The carrying capacity of $P$. aibuhitensis ranged from 94 to 148 ind. $\mathrm{m}^{-2}$ (Fig. 5). Higher carrying capacity (130-150 ind. $\mathrm{m}^{-2}$ ), accounting for $66.38 \%$ of the total area, was mainly distributed in the central and western regions (around Stns 4-6, 8, 10-12) of the study area. Only a few spot-like regions exhibited a carrying capacity $<130$ ind. $\mathrm{m}^{-2}$. The carrying capacity of the eastern region (Stns 1-3) was less than the average, especially at $\operatorname{Stn} 3\left(90\right.$ ind. $\left.\mathrm{m}^{-2}\right)$.

Table 3. Suitable habitat area $\left(\mathrm{km}^{2}\right.$ and \% of total area) of 6 different classes of habitat suitability index for Perinereis aibuhitensis in the estuarine wetlands of the Zhimai River

\begin{tabular}{|lccccccc}
\hline & \multicolumn{1}{c}{} & & & & \\
\cline { 2 - 6 } & $0.64-0.7$ & $0.7-0.75$ & $0.75-0.8$ & $0.8-0.85$ & $0.85-0.9$ & $0.9-0.95$ \\
\hline Area $\left(\mathrm{km}^{2}\right)$ & 0.060 & 0.141 & 0.263 & 0.218 & 0.819 & 0.025 \\
Percent $(\%)$ & 3.93 & 9.24 & 17.23 & 14.29 & 53.67 & 1.64 \\
\hline
\end{tabular}

Table 4. Area covered $\left(\mathrm{km}^{2}\right)$ and Perinereis aibuhitensis abundance $\left(\times 10^{6}\right.$ ind. per class $)$ in 6 different classes of carrying capacity for $P$. aibuhitensis in the estuarine wetlands of the Zhimai River

\begin{tabular}{|c|c|c|c|c|c|c|c|}
\hline & \multicolumn{7}{|c|}{ - Carrying capacity (ind. $\mathrm{m}^{-2}$ ) } \\
\hline & $90-100$ & $100-110$ & $110-120$ & $120-130$ & $130-140$ & $140-150$ & Total \\
\hline Area $\left(\mathrm{km}^{2}\right)$ & 0.018 & 0.094 & 0.178 & 0.197 & 0.325 & 0.688 & 1.500 \\
\hline Abundance $\left(\times 10^{6}\right.$ ind. $)$ & 1.71 & 9.87 & 20.47 & 24.63 & 43.88 & 99.76 & 203.12 \\
\hline
\end{tabular}




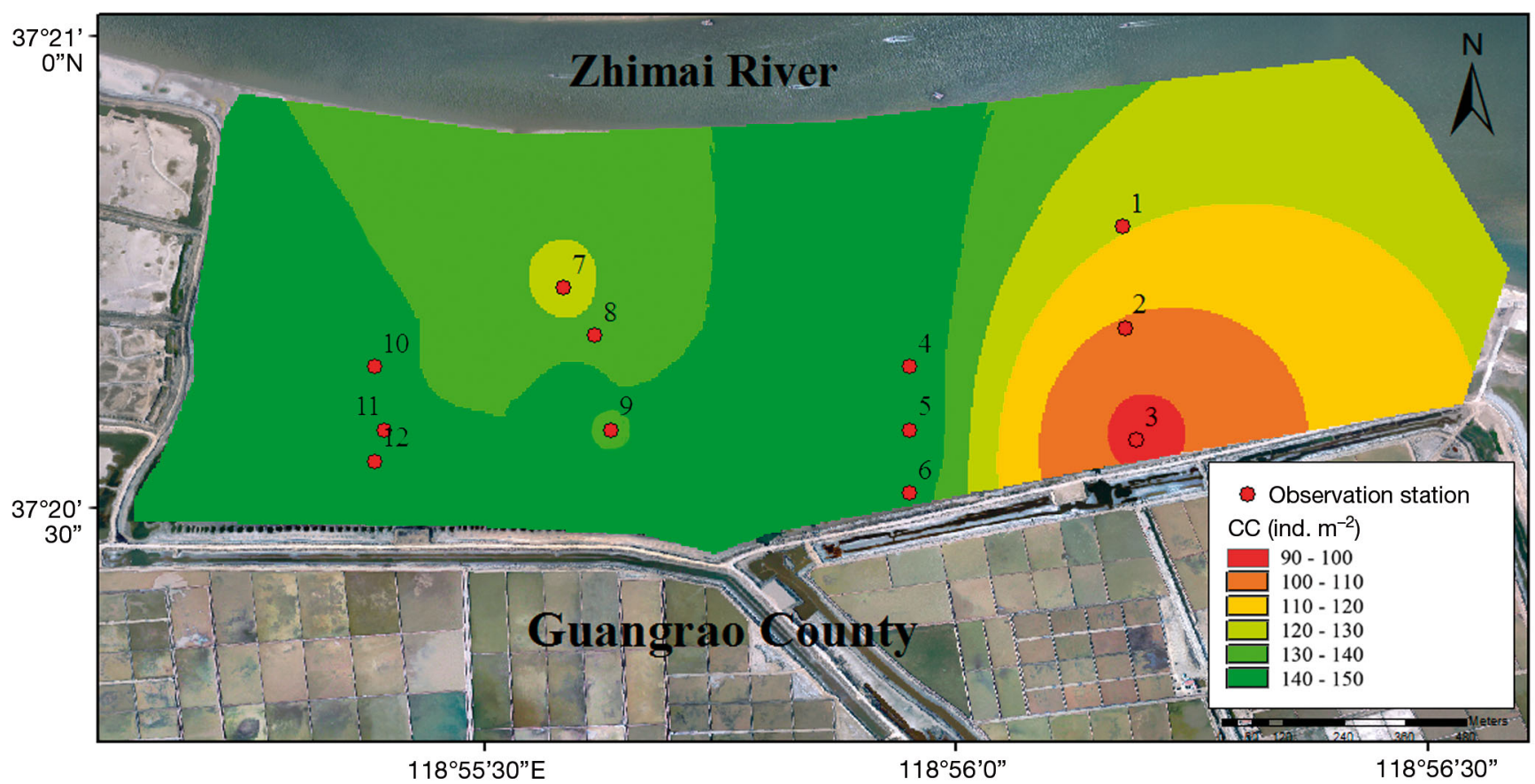

Fig. 5. Carrying capacity (CC) map for Perinereis aibuhitensis carrying capacity in the estuarine wetlands of the Zhimai River

The areas with a carrying capacity $<100$ ind. $\mathrm{m}^{-2}$ only comprised $0.018 \mathrm{~km}^{2}$, accounting for $1.2 \%$ of the total area.

\section{DISCUSSION}

\section{Analysis of Perinereis aibuhitensis carrying capacity: implications for restoration}

In general, the total estimated $P$. aibuhitensis carrying capacities in estuarine wetlands of northern China are comparable with those reported in other studies (Fauchald 1986, Zhao et al. 1993). Mobile species have strong selection preferences for various habitats that determine their relative abundance (Steenweg et al. 2016). There were 2 main areas with a relatively low carrying capacity $\left(<130\right.$ ind. $\left.\mathrm{m}^{-2}\right)$ in the study area, namely the eastern region and Stn 7 . The SI map of each parameter factor can help determine the reasons for the differences in carrying capacity in this region.

The SI value of sand content was low at Stns 1-3 (Fig. 6A). This is because the sand content of these stations $(59.28,64.91$, and $69.95 \%$, respectively) exceeded the upper limitation of the most suitable sand content (range: 25-50\%). Moreover, around Stn 3, the SI value of $\mathrm{pH}$ was relatively low (Fig. 6C). These factors may be responsible for the low carrying capacity in the eastern region. This is comparable with the findings from Cai \& Li (1995) and Zhang \& $\mathrm{Hu}$ (2008). Zhang \& Hu (2008) found that a higher sand factor could significantly influence the feeding rate of $P$. aibuhitensis based on the relationship between sediment and feeding in this species. Cai \& Li (1995) compared distributions of Polychaeta in the Minnan-Taiwan Shoal and reported that the optimal sediment composition for Polychaeta is a high proportion of silt and clay, and a specific percentage of sand $(25-50 \%)$.

Another low carrying capacity area was identified around Stn 7. Although the SI value of $\mathrm{pH}$ at $\operatorname{Stn} 7$ was the highest, the salinity was very low (for SI values, see Fig. 6B,C). The low salinity is due to the low terrain in this area, which results in rainwater accumulation. Moreover, the salinity weight $(0.1724)$ was higher than that for $\mathrm{pH}(0.0194)$. These effects most likely resulted in the low HSI value and carrying capacity at this station. Zhou et al. (2007) also highlighted that a specific suitable salinity and $\mathrm{pH}$ are necessary for all life stages of $P$. aibuhitensis, but especially during fertilization and hatching.

All SI values of environmental pollution factors (petroleum hydrocarbon, copper, cadmium, lead, and sulfide) were 1, indicating that their effect on $P$. aibuhitensis growth and reproduction was negligible in the study area. The difference in environmental quality factors (sand content, salinity, and $\mathrm{pH}$ ) there- 

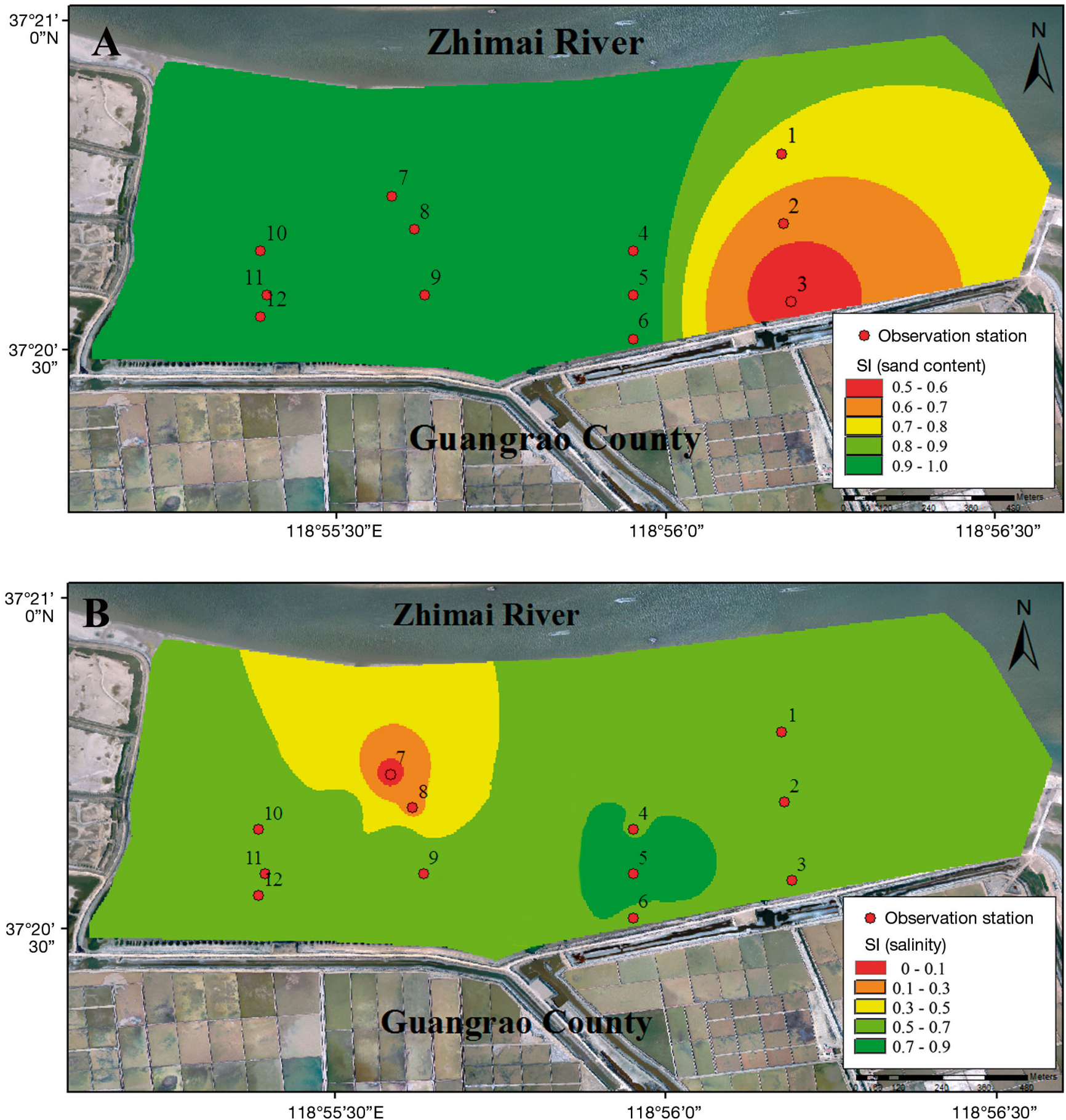

Fig. 6 (continued on next page). Suitability index maps of the environmental quality factors (A) sand content, (B) salinity, and (C) $\mathrm{pH}$ for Perinereis aibuhitensis in the estuarine wetlands of the Zhimai River

fore appears to be the main reason for the diversity in the carrying capacity of this region.

To provide a reasonable and feasible proposal for $P$. aibuhitensis conservation and restoration in the estuarine wetlands of the Zhimai River, carrying capacity from field surveys was compared with esti- mated carrying capacity. Generally, the 6 stations' (Stns 1, 2, 3, 7, 8, and 9) field survey carrying capacities were lower than the estimated carrying capacities, particularly at Stns 2 (61 versus 108 ind. $\mathrm{m}^{-2}$, respectively), 3 ( 27 versus 90 ind. $\mathrm{m}^{-2}$ ), and 7 (88 versus 125 ind. $\mathrm{m}^{-2}$ ) (Table 5). The abundances of $P$. aibuhitensis 


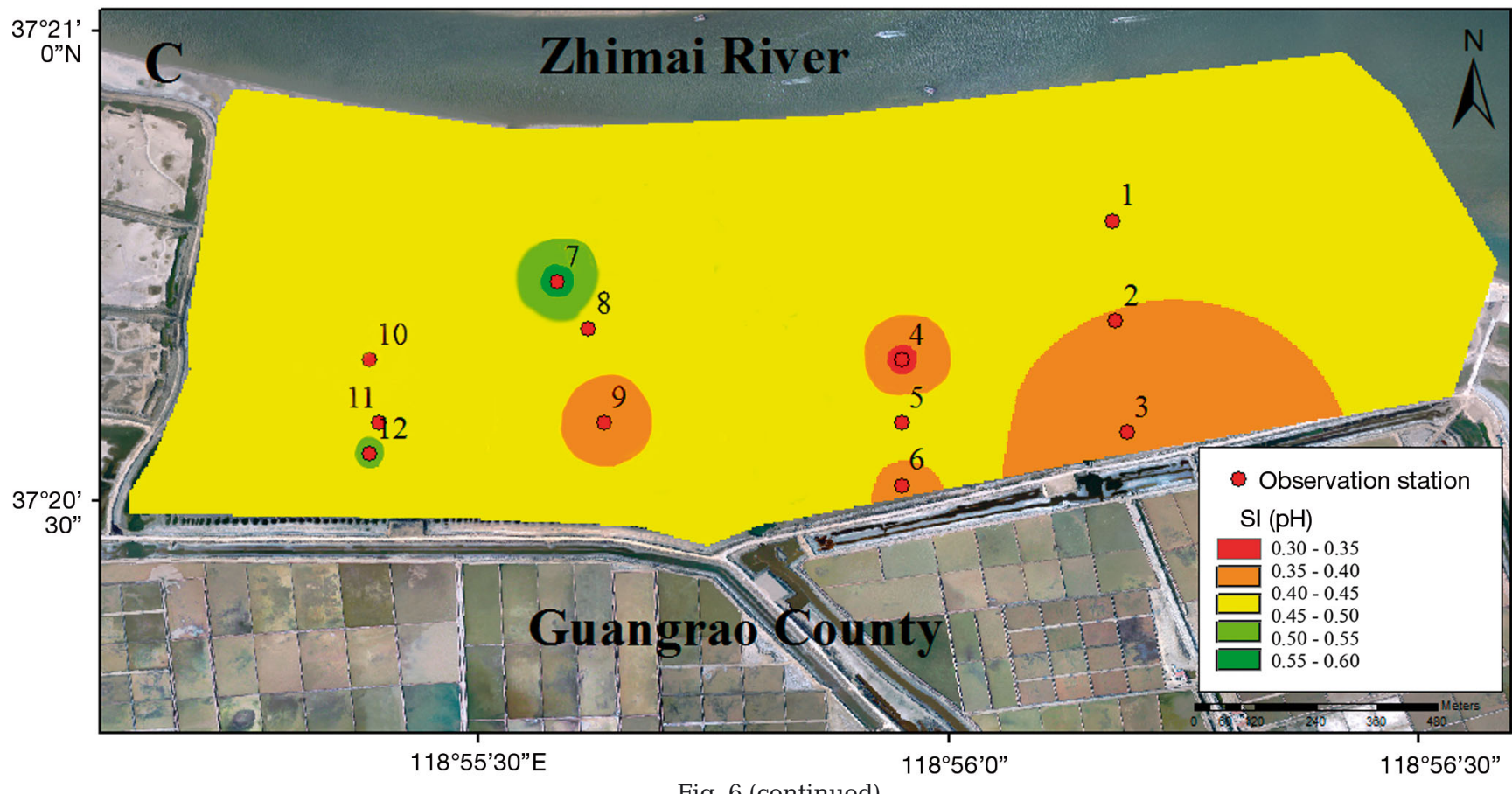

did not reach the environmental carrying capacity, especially around Stn 7 and in the eastern region. These areas should therefore be considered as recovery areas; an appropriate density of $P$. aibuhitensis should be allocated in these areas. Moreover, as a cavedwelling benthic organism, $P$. aibuhitensis can significantly improve the environmental parameters of the sediment (increase dissolved oxygen, reduce heavy metal, and recycle organic matter) due to their continuous movement (Fauchald 1986, Zhou et al. 2007). Consequently, this will increase the HSI for other fauna and flora in this region. This highlights the importance of $P$. aibuhitensis restoration in the estuarine wetlands of the Zhimai River.

\section{Assessment of the HSI model}

With the purpose of restoring ecological environments and sustainable development, increasing

Table 5. Perinereis aibuhitensis carrying capacity assessments, based on field surveys and model estimates

\begin{tabular}{|c|c|c|c|c|c|c|}
\hline & \multicolumn{6}{|c|}{ Station } \\
\hline & 1 & 2 & 3 & 7 & 8 & 9 \\
\hline Field survey (ind. $\mathrm{m}^{-2}$ ) & 100 & 61 & 27 & 88 & 92 & 148 \\
\hline $\begin{array}{l}\text { Model estimate } \\
\left(\text { ind. } \mathrm{m}^{-2} \text { ) }\right.\end{array}$ & 121 & 108 & 90 & 125 & 133 & 148 \\
\hline
\end{tabular}

amounts of attention have been paid to habitat suitability and species carrying capacity (Hirzel et al. 2006). Different approaches have been adopted in the estimation of benthic carrying capacity (Edgar 1993, Vincenzi et al. 2006, Byron et al. 2011).

Considering the aspect of food flux, Edgar (1993) proposed a metabolic rate-based index model to calculate the epifaunal carrying capacity in island and estuarine habitats. Habitat carrying capacity levels were expressed as an index of total community consumption by summing the body masses of individual animals. Food production and consumption within habitats were directly determined in the study by Edgar (1993); therefore, the methodology was convenient and simple. However, the precondition of the model requires that environmental factors, such as predator abundance, water temperature, and salinity, have little influence on research species. Therefore, the metabolic rate-based index model cannot be applied to estimate the carrying capacity of most estuarine wetland species. In our study, parameter factors were selected for comprehensive assessment of the habitat suitability of the study area, and the carrying capacity was estimated based on the relationships in an HSI model. This methodology can be easily transferred to other coastal and estuary habitats.

Ecopath is a static, mass-balance, ecosystem-based modeling software that focuses on energy transfer between trophic levels; it is widely used in ecological studies (Vasconcellos et al. 1997). It encompasses the 
full trophic spectrum, making it an appropriate ecosystem modeling tool for determining ecological carrying capacity (Monaco \& Ulanowicz 1998, Jiang \& Gibbs 2005). Byron et al. (2011) estimated the ecological oyster carrying capacity of Narragansett Bay with the Ecopath model. Compared with Byron et al. (2011), the method used in the present study is simple and lacks complex mass-balance models. A more carefully calibrated, complex trophic/dynamical model would provide more useful information on nutrient cycling and allow for a more detailed analysis of species' ecological carrying capacity. However, little is known about the Zhimai River estuary, limiting the utilization of such a model. Overall, the approach adopted in the present study was a reasonable compromise between simplicity and the complexity of other ecosystem models.

The HSI model, like any other model, has advantages and disadvantages. Increasing the accuracy of the results and other improvements are needed to optimize the model in the future. Other internal or external factors may also influence the growth of $P$. aibuhitensis, such as pathogens, predators and competition, water temperature, and other forms of natural or anthropogenic disturbance. Moreover, the carrying capacity formulation for $P$. aibuhitensis should be more accurately constructed in order to minimize the differences between predicted and observed yield.

\section{CONCLUSIONS}

An HSI model was applied to quantitatively and qualitatively analyze $P$. aibuhitensis carrying capacity in the estuarine wetlands of the Zhimai River. Results showed that the central and western region have a relatively high carrying capacity, whereas that of the eastern region is below average. Under the present conditions, $P$. aibuhitensis abundances did not reach the carrying capacity of the environment, particularly in the eastern region. Initiation of species restoration in this area is feasible and urgent; the area around Stn 7 and the eastern region are recommended as the main recovery areas. Despite lack of scientific validation, it is believed that this approach (HSI model with GIS) can provide feasible and effective management for other aquaculture species (such as fish, shrimps, and crabs).

Acknowledgements. This study was jointly funded by the National Natural Science Foundation of China (NSFC) (no. 41206102), the National Marine Public Welfare Research of China (no. 201305009), and the Major Agricultural Application Technology Innovation Project of Shandong Province.

\section{LITERATURE CITED}

Acevedo P, Cassinello J (2009) Human-induced range expansion of wild ungulates causes niche overlap between previously allopatric species: red deer and Iberian ibex in mountainous regions of southern Spain. Ann Zool Fenn 46:39-50

Ahn IY, Kang YC, Choi JW (1995) The influence of industrial effluents on intertidal benthic communities in Panweol, Kyeonggi Bay (Yellow Sea) on the west coast of Korea. Mar Pollut Bull 30:200-206

Alves JPH, Passos EA, Garcia CAB (2007) Metals and acid volatile sulfide in sediment cores from the Sergipe River Estuary, Northeast, Brazil. J Brazil Chem Soc 18:748-758

Bai J, Xiao R, Cui B, Zhang K and others (2011) Assessment of heavy metal pollution in wetland soils from the young and old reclaimed regions in the Pearl River Estuary, South China. Environ Pollut 159:817-824

Brach M, Kaczmarowski J (2014) Suitability of the HSI model for the analysis of the forest fire spread. Tohoku J Exp Med 158:769-778

* Brown S, Schreier H, Thompson WA, Vertinsky I (1994) Linking multiple accounts with GIS as decision support system to resolve forestry/wildlife conflicts. J Environ Manage 42:349-364

Byron C, Link J, Costa-Pierce B, Bengtson D (2011) Calculating ecological carrying capacity of shellfish aquaculture using mass-balance modeling: Narragansett Bay, Rhode Island. Ecol Modell 222:1743-1755

Cai L, Li F (1995) Distribution of polychaetes in MinnanTaiwan shoal fishing ground. J Oceanogr Taiwan Strait 2:144-149 (in Chinese with English Abstract)

Cai DY, Yan XZ (2014) Effects of salinity on oxygen consumption rate and ammonia $\mathrm{N}$ excretion rate of Perinereis aibuhitensis. Mark Sci 38:54-59 (in Chinese with English Abstract)

Carter GM, Stolen ED, Breininger DR (2006) A rapid approach to modeling species-habitat relationships. Biol Conserv 127:237-244

Chen Y, Yu J, Khan S (2013) The spatial framework for weight sensitivity analysis in AHP-based multi-criteria decision making. Environ Model Softw 48:129-140

* Chiba M, Shinohara A, Matsushita K, Watanabe H, Inaba Y (1996) Indices of lead-exposure in blood and urine of lead-exposed workers and concentrations of major and trace elements and activities of SOD, GSH-Px and catalase in their blood. Tohoku J Exp Med 178:49-62

* Davey JT, Watson PG (1995) The activity of Nereis diversicolor (Polychaeta) and its impact on nutrient fluxes in estuarine waters. Ophelia 41:57-70

* Downs JA, Gates RJ, Murray AT (2008) Estimating carrying capacity for sandhill cranes using habitat suitability and spatial optimization models. Ecol Modell 214:284-292

* Durou C, Mouneyrac C, Amiard-Triquet C (2005) Tolerance to metals and assessment of energy reserves in the polychaete Nereis diversicolor in clean and contaminated estuaries. Environ Toxicol 20:23-31

* Durou C, Smith BD, Roméo M, Rainbow PS and others (2007) From biomarkers to population responses in Nereis diversicolor: assessment of stress in estuarine ecosystems. Ecotoxicol Environ Saf 66:402-411

Edgar GJ (1993) Measurement of the carrying capacity of benthic habitats using a metabolic-rate based index. Oecologia 95:115-121

Fauchald K (1986) The Nereidae (polychaetous annelids) of 
the Chinese Coast. Q Rev Biol 61:412

Gu X, Jin C (2002) Biological characteristics of Perinereis aibuhitensis Grube and status of its utilization. Modern Fish Inf 71:876 (in Chinese with English Abstract)

Gumusay MU, Koseoglu G, Bakirman T (2016) An assessment of site suitability for marina construction in Istanbul, Turkey, using GIS and AHP multicriteria decision analysis. Environ Monit Assess 188:677

* Guyondet T, Comeau LA, Bacher C, Grant J, Rosland R, Sonier R, Filgueira R (2015) Climate change influences carrying capacity in a coastal embayment dedicated to shellfish aquaculture. Estuaries Coasts 38:1593-1618

Hickey L (2008) Assessing re-colonization of moose in New York with HSI models. Alces 44:117-126

*Hirzel AH, Le Lay G, Helfer V, Randin C, Guisan A (2006) Evaluating the ability of habitat suitability models to predict species presences. Ecol Modell 199:142-152

Jiang W, Gibbs MT (2005) Predicting the carrying capacity of bivalve shellfish culture using a steady, linear food web model. Aquaculture 244:171-185

Knudson MD, Vanlooy JA, Hill MJ (2015) A habitat suitability index (HSI) for the western prairie fringed orchid (Platanthera praeclara) on the Sheyenne National Grassland, North Dakota, USA. Ecol Indic 57:536-545

Littleboy M, Smith DM, Bryant MJ (1996) Simulation modelling to determine suitability of agricultural land. Ecol Modell 86:219-225

Luan X, Qu Y, Li D, Liu S, Wang X, Wu B, Zhu C (2011) Habitat evaluation of wild Amur tiger (Panthera tigris altaica) and conservation priority setting in north-eastern China. J Environ Manage 92:31-42

Lv F, Huang J, Lv L (2009) Study on the toxicities of ammonia-N to Perinereis aibuhitensis under different salinities. J Anhui Agric Sci 7:061 (in Chinese with English Abstract)

Mathys L, Zimmermann NE, Zbinden N, Suter W (2006) Identifying habitat suitability for hazel grouse Bonasa bonasia at the landscape scale. Wildl Biol 12:357-366

McKeon G, Stone G, Syktus J, Carter J and others (2009) Climate change impacts on northern Australian rangeland livestock carrying capacity: a review of issues. Rangeland J 31:1-29

Miron G, Kristensen E (1993) Factors influencing the distribution of nereid polychaetes: the sulfide aspect. Mar Ecol Prog Ser 93:143-153

Monaco M, Ulanowicz R (1998) Comparative ecosystem trophic structure of three US mid-Atlantic estuaries. Oceanogr Lit Rev 8:1406-1407

Ng TYT, Rainbow PS, Amiard-Triquet C, Amiard JC, Wang WX (2008) Decoupling of cadmium biokinetics and metallothionein turnover in a marine polychaete after metal exposure. Aquat Toxicol 89:47-54

Ortigosa GR, De Leo GA, Gatto M (2000) VVF: integrating modelling and GIS in a software tool for habitat suitability assessment. Environ Model Softw 15:1-12

Osborne PE, Alonso J, Bryant R (2001) Modelling landscapescale habitat use using GIS and remote sensing: a case study with great bustards. J Appl Ecol 38:458-471

Reish DJ, Gerlinger TV (1997) A review of the toxicological studies with polychaetous annelids. Bull Mar Sci 60: 584-607

Ripple WJ, Lattin PD, Hershey K, Wagner FF, Meslow EC (1997) Landscape composition and pattern around northern spotted owl nest sites in southwest Oregon. J Wildl Manag 61:151-158
Saaty TL (1977) A scaling method for priorities in hierarchical structures. J Math Psychol 15:234-281

Saaty TL, Vargas LG (1991) Prediction, projection and forecasting: applications of the analytic hierarchy process in economics, finance, politics, games and sports. Kluwer Academic Pub, Dordrecht

* Shao K, Ji J, Zhou B (2015) Habitat suitability analysis of Suaeda heteroptera in wetlands of Laizhou West Bank based on GIS. Aquat Sci Technol 4:8-16

* Shen G, Feng C, Xie Z, Ouyang Z, Li J, Pascal M (2008) Proposed conservation landscape for giant pandas in the Minshan Mountains, China. Conserv Biol 22:1144-1153

Shi X (1993) Effects of several ecological factors on early stage survival and growth of Perinereis aibuhitensis. Shengtaixue Zazhi 5:21-24 (in Chinese with English Abstract)

* Steenweg R, Hebblewhite M, Gummer D, Low B, Hunt B (2016a) Assessing potential habitat and carrying capacity for reintroduction of plains bison (Bison bison bison) in Banff National Park. PLOS ONE 11:e0150065

พ Store R, Jokimäki J (2003) A GIS-based multi-scale approach to habitat suitability modeling. Ecol Modell 169:1-15

* Store R, Kangas J (2001) Integrating spatial multi-criteria evaluation and expert knowledge for GIS-based habitat suitability modelling. Landsc Urban Plan 55:79-93

Sun FH, Zhou QX, Zhang QR (2006) Toxic effects of petroleum hydrocarbons and copper on polychaete Nereis diversicolor and on its antioxidant enzyme systems. Huan Jing Ke Xue 27:1415-1419

* Sun F, Zhou Q, Wang M, An J (2009) Joint stress of copper and petroleum hydrocarbons on the polychaete Perinereis aibuhitensis at biochemical levels. Ecotoxicol Environ Saf 72:1887-1892

* Tian Y, Liu H, Wang Q, Zhou J, Tang X (2014) Acute and chronic toxic effects of $\mathrm{Pb}^{2+}$ on polychaete Perinereis aibuhitensis: morphological changes and responses of the antioxidant system. J Environ Sci 26:1681-1688

USFWS (1981) Standards for the development of habitat suitability index models. US Fish and Wildlife Service, Washington, DC

Ushakova OO, Sarantchova OL (2004) The influence of salinity on fertilization and larval development of Nereis virens (Polychaeta, Nereidae) from the White Sea. J Exp Mar Biol Ecol 301:129-139

*Vasconcellos M, Mackinson S, Sloman K, Pauly D (1997) The stability of trophic mass-balance models of marine ecosystems: a comparative analysis. Ecol Modell 100: 125-134

Vincenzi S, Caramori G, Rossi R, Leo GAD (2006) A GISbased habitat suitability model for commercial yield estimation of Tapes philippinarum in a Mediterranean coastal lagoon (Sacca di Goro, Italy). Ecol Modell 193: 90-104

Vincenzi S, Zucchetta M, Franzoi P, Pellizzato M, Pranovi F, De Leo GA, Torricelli P (2011) Application of a random forest algorithm to predict spatial distribution of the potential yield of Ruditapes philippinarum in the Venice lagoon, Italy. Ecol Modell 222:1471-1478

Wang J, Zhou QX, Zhang QR, Zhang Y (2007) Toxic effects of petroleum hydrocarbons, copper and cadmium on polychaete Perinereis aibuhitensis Grube and on its responses in acetycholinesterase activity. Huan Jing Ke Xue 28:1796-1801

* Wang J, Zhou Q, Zhang Q, Zhang Y (2008a) Single and joint effects of petroleum hydrocarbons and cadmium on the 
polychaete Perinereis aibuhitensis Grube. J Environ Sci 20:68-74

Wang X, Zhong X, Liu S, Liu J, Wang Z, Li M (2008b) Regional assessment of environmental vulnerability in the Tibetan Plateau: development and application of a new method. J Arid Environ 72:1929-1939

Won EJ, Lee JS, Lee YM (2013) Combined effects of cadmium and copper on the expression of antioxidant enzyme-coding genes in the polychaete, Perinereis nuntia. Toxicol Environ Health Sci 5:26-33

Yang X, Yuan X, Zhang A, Mao Y and others (2015) Spatial distribution and sources of heavy metals and petroleum hydrocarbon in the sand flats of Shuangtaizi Estuary, Bohai Sea of China. Mar Pollut Bull 95:503-512

Yuan X, Chen A, Zhou Y, Liu Y, Yang D (2010) The influence of cadmium on the antioxidant enzyme activities in polychaete Perinereis aibuhitensis Grube (Annelida: Poly-

Editorial responsibility: Catriona MacLeod,

Hobart, Tasmania, Australia chaeta). Chin J Oceanol Limnol 28:849-855

* Zajac Z, Stith B, Bowling AC, Langtimm CA, Swain ED (2015) Evaluation of habitat suitability index models by global sensitivity and uncertainty analyses: a case study for submerged aquatic vegetation. Ecol Evol 5: 2503-2517

Zhang Q, Hu G (2008) Study on feeding natural sediment of Perinereis aibuhitensis. J Tianjin Univ Sci Technol 3:011 (in Chinese with English Abstract)

Zhao Q, Zhao Q, Xu J (1993) A study of annual fluctuation of biomass of Perinereis aibuhitensis in Qidong, Jiangsu Province. J Nanjing Normal Univ (Nat Sci Edn) 1:011 (in Chinese with English Abstract)

Zhou Y, Yang D, Guan Z, Zhao F (2007) Technique for artificial breeding and culture of Perinereis aibuhitensis Grube in ponds. Fish Sci 26:150-153 (in Chinese with English Abstract)

Submitted: November 2, 2016; Accepted: June 19, 2017 Proofs received from author(s): August 23, 2017 